\title{
AIR KELAPA MUDA TERHADAP NYERI HAID
}

\author{
Suri Gusmiyanti Fitriyah ${ }^{1}$, Sunarsih ${ }^{2}$, Yulistiana Evayanti ${ }^{2}$ \\ ${ }^{1}$ Program Studi Kebidanan Universitas Malahayati \\ ${ }^{2}$ Dosen Program Studi D IV Kebidanan Universitas Malahayati
}

[Email Korespondensi: surigusmifitriyah@gmail.com]

\begin{abstract}
Young Coconut Water Against Menstrual Pain. The high prevalence and The high prevalence and morbidity rates of menstrual pain with The world incidence is on average between $16.8-81 \%$, in Indonesia it is $64.8 \%$ and in Bandar Lampung ranks first in the complaints experienced by women in 2014, Consumption of herbal drinks such as young coconut water can reduce menstrual pain. The research objectives are known the effect of giving young coconut water to menstrual yeri in young women at SMK Negeri 1 Bandar Lampung in 2020. With the research method quasi experimentwith, the research subjects were 40 grade girls of SMKN 1 Bandar Lampung. Data was collected from 7 February - 1 July 2020, analyzed test $t$-independent. Obtained research results score average menstrual pain in the intervention group of 4.10 and the control group of 6.15. It was found that the consumption of young coconut water had an effect on menstrual pain in female adolescents at SMK Negeri 1 Bandar Lampung, statistically it had a significant effect with $\mathrm{p}$-value $=0.000$ or $<0.05$. AThere is the effect of giving young coconut water on menstrual pain in young women at SMK Negeri 1 Bandar Lampung. It is hoped that teenagers can make young coconut water as a complementary treatment of menstrual pain.
\end{abstract}

Keywords : Young Coconut Water, Pain during Menstruation

Abstrak: Air Kelapa Muda Terhadap Nyeri Haid. Tingginya angka prevalensi dan morbiditas dari nyeri haid dengan insidensi didunia rata-rata antara 16,8 $81 \%$, di Indonesia sebesar $64,8 \%$ dan di Bandar Lampung menempati urutan pertama keluhan yang sering dialami wanita pada tahun 2014, Konsumsi minuman herbal seperti air kelapa muda dapat mengurangi nyeri haid. Diketahui pengaruh pemberian air kelapa muda terhadap nyeri haid pada remaja putri Di SMK Negeri 1 Bandar Lampung Tahun 2020.Dengan metode penelitian quasi eksperimen, subjek penelitian adalah remaja putri kelas IX SMKN 1 Bandar Lampung berjumlah 40 responden. Data dikumpulkan sejak tanggal 7 Februari - 1 juli 2020, dianalisis data menggunakan uji $t$-independent. Didapatkan hasil penelitian nilai rata-rata nyeri menstruasi kelompok intervensi sebesar 4,10 dan kelompok kontrol sebesar 6,15. Didapatkan mengkonsumsi air kelapa muda berpengaruh terhadap nyeri haid remaja putri di SMK Negeri 1 Bandar Lampung, secara statistik mempunyai pengaruh yang bermakna dengan $p$-value $=0.000$ atau $<0.05$. Adapengaruhpemberianairkelapamudaterhadap nyeri haid remaja putri di SMK Negeri 1 Bandar Lampung. Diharapkan para remaja dapat menjadikan air kelapa muda sebagai salah satu pengobatan komplementer nyeri haid.

Kata kunci :Air Kelapa Muda, Nyeri saat Haid

\section{PENDAHULUAN}

Dysmenorrhea adalah nyeri saat haid, biasanya dengan rasa kram dan terpusat di abdomen bawah. Keluhan nyeri haid dapat terjadi bervariasi mulai dari yang ringan sampai dengan yang berat(Prawirahardjo,2011,). Nyeri haid yang dirasakan setiap individu dapat berbeda antara satu dengan yang lainnya. Secara etimologi nyeri 
haid (Dysmenorrhea) berasal dari bahasa Yunani kuno, dys yang berarti sulit, nyeri, abnormal; meno yang haid (dysmenorrhea) adalah aliran menstruasi yang sulit atau aliran menstruasi yang mengalami nyeri, penanganan nyeri haid (Dysmenorrhea) dapat dilakukan dengan cara yaitu, secara farmakologi dan non farmakologi (Anurogo\& Wulandari, A. 2011)

Terapi farmakologi antara lain, pemberian obat analgetik (Terapi novalgin, ponstan, acetaminophen) serta terapi hormonal, sedangkan terapi non farmakologi antara lain,terapi es panas, pemberian penjelasan dan nasehat, pengobatan herbal (kayu manis, air kelapa muda, cengkeh, ketumbar, kunyit, bubuk pala, jahe) dan Relaksasi (Anurogo \& Wulandari,2011).

Air kelapa muda merupakan salah satu minuman herbal yang mempunyai khasiat mengurangi nyeri haid, selain gampang untuk kita dapatkan dan praktis untuk kita bawa kemana-mana, jika dibandingkan air kelapa tua, air kelapa muda tampaknya memiliki kandungan nutrisi yang lebih ideal. (Putri,2019) air kelapa muda kaya akan mineral dan vitamin di antaranya mengandung Kalsium 14,11 Mg/100 $\mathrm{ml}$, Magnesium 25,0 Mg/100ml, Vitamin C 2,40 Mg/100ml serta Zn $0.10 \mathrm{Mg} / 100 \mathrm{ml}$. Kalsium dan Magnesium yang terkandung dalam air kelapa dapat mengurangi ketegangan otot dan Vitamin C yang merupakan zat-zat alami anti inflamasi yang membantu meringankan rasa sakit akibat kram menstruasi dengan menghambat enzimcyclooxygenase yang memiliki peran dalam mendorong proses pembentukan prostaglandin (Kristina \&Syahid, 2012).

Salah satu fungsi air kelapa adalah sebagai minuman isotonik karena mengandung elektrolit yang melimpah, ketika menstruasi seorang wanita banyak kehilangan darah, mengkonsumsi air kelapa merupakan salah satu pengganti cairan tubuh yang hilang akibat menstruasi juga sebagai pereda kram yang dirasakan saat berarti bulan; dan rrhea yang berarti aliran atau arus. Disimpulkan bahwa nyeri menstruasi (Putri,2019) Penelitian yang dilakukan dalam jurnal yang berjudul Cocos nucifera (L.) (Arecaceae) A phytochemical and pharmacological review oleh Lima, dkk (2015) menyatakan bahwa di India air kelapa dibuat menjadi infus (pengganti cairan tubuh). Air kelapa mengandung efek biologis, seperti antihelminthic, antiinflamasi, aktivitas antinosiseptif, antioksidan, antijamur, antimikroba, dan antitumor yang dapat membantu mengurangi rasa nyeri saat menstriasi (Dysmenorrhea) dan gangguan haid lainnya yang telah digunakan dibeberapa negara sebagai obat alternatif/herbal yang ampuh.

Sekolah Menengah Kejuruan Negeri 1 Bandar Lampung merupakan salah satu Sekolah Kejuruan Negeri yang ada di Kota Bandar Lampung yang sebagian besar berada pada golongan umur remaja menengah. Hasil observasi data register UKS SMKN 1 Bandar Lampung didapat data bahwa kejadian nyeri haid pada tahun 2018 dialami oleh 40 siswi, dan meningkat di tahun 2019 menjadi sebesar 78 siswi (Data Register UKS SMKN 1 Bandar Lampung, 2018-2019).

Berdasarkan hasil pre survey yang peneliti lakukan pada tanggal 7 Februari 2020 di SMKN 1 Bandar Lampung kepada 30 siswi melalui teknik wawancara didapat 20 orang $(70 \%)$ siswi mengatakan sering mengalami gejala nyeri perut pada saat menjelang dan saat menstruasi berlangsung sehingga menyebabkan rata-rata dalam sebuah absensi kehadiran pada saat proses belajar mengajar ataupun istirahat di rumah 12 hari. Upaya yang dilakukan pihak sekolah untuk mengatasi keluhan nyeri haid adalah dengan memberikan obat analgesik seperti, Paracetamol dan Asam Mefenamat.

\section{METODE}

Jenis penelitian adalah kuantitatif dan rancangan yang digunakan dalam penelitian ini adalah quasi eksperimen 
desain penelitian Intact Group Comparison adalah suatu penelitian eksperimen yang dilakukan dengan cara memberikan perlakuan pada tidak diberi perlakuan/diberi perlakuan berbeda)(Sugiyono, 2016).

Penelitian dilakukan pada remaja putri kelas XI di SMKN 1 Bandar Lampung, responden dalam penelitian ini adalah remaja putri yang menderita nyeri saat haid dan memenuhi kriteria inklusi sejumlah 40 responden yang didapatkan dengan menggunakan teknik purposive sampling, Variabel dalam penelitian ini adalah tentang pengaruh pemberian air kelapa muda terhadap nyeri haid. Intervensi dilakukan dengan memberikan air kelapa muda sebanyak 400 cc untuk setengah kelompok untuk eksperimen (yang diberi perlakuan) dan setengah untuk kelompok kontrol (yang

diminum 2 kali yaitu pada pagi hari pukul 08:00 WIB dan siang hari pukul 15:00 WIB, pada hari ke1 haid sampai dengan hari ke 3 haid Intensitas nyeri didapatkan dengan menggunakan skala Numerical Rating Scale (NRS) yang merupakan salah satu alat ukur untuk menilai tingkat nyeri yang dialami pasien sesuai subjektivitas pasien tersebut, Analisa data dilakukan dengan bantuan program komputer (SPSS). Analisa data univariat dilakukan untuk mengetahui distribusi frekuensi, analisa bivariate dilakukan dengan t-test.

HASIL

Tabel 1. Distribusi Frekuensi

\begin{tabular}{|c|c|c|c|}
\hline No & $\begin{array}{c}\text { Usia } \\
\text { Responden }\end{array}$ & $\begin{array}{c}\text { Kelompok Intervensi } \\
\text { Frekuensi }(\%)\end{array}$ & $\begin{array}{c}\text { Kelompok Kontrol } \\
\text { Frekuensi (\%) }\end{array}$ \\
\hline 1. & 15 Tahun & $2(10 \%)$ & $2(10 \%)$ \\
\hline 2. & 16 Tahun & $11(55 \%)$ & $12(60 \%)$ \\
\hline 3. & 17 Tahun & $7(35 \%)$ & $6(30 \%)$ \\
\hline Total & & $20(100 \%)$ & $20(100 \%)$ \\
\hline No & $\begin{array}{c}\text { Usia } \\
\text { Menarche }\end{array}$ & Frekuensi (\%) & Frekuensi (\%) \\
\hline 1. & 10 Tahun & $5(25 \%)$ & $5(25 \%)$ \\
\hline 2. & 11 Tahun & $7(35 \%)$ & $7(35 \%)$ \\
\hline 3. & 12 Tahun & $8(40 \%)$ & $8(35 \%)$ \\
\hline Total & & $20(100 \%)$ & $20(100 \%)$ \\
\hline No & $\begin{array}{c}\text { Siklus } \\
\text { Menstruasi }\end{array}$ & Frekuensi (\%) & Frekuensi \\
\hline 1. & 27 hari & $1(5 \%)$ & $1(5 \%)$ \\
\hline 2. & 30 hari & $17(85 \%)$ & $18(90 \%)$ \\
\hline 3. & 36 hari & $2(10 \%)$ & $1(5 \%)$ \\
\hline Total & & $20(100 \%)$ & $20(100 \%)$ \\
\hline No & $\begin{array}{c}\text { Lama } \\
\text { Menstruasi }\end{array}$ & Frekuensi (\%) & Frekuensi \\
\hline 1. & 4 hari & $2(10 \%)$ & $2(10 \%)$ \\
\hline 2. & 5 hari & $5(25 \%)$ & $5(25 \%)$ \\
\hline 3. & 6 hari & $9(45 \%)$ & $10(50 \%)$ \\
\hline 4. & 7 hari & $4(20 \%)$ & $3(15 \%)$ \\
\hline Total & & $20(100 \%)$ & $20(100 \%)$ \\
\hline
\end{tabular}

Berdasarkan tabel terlihat bahwa karakteristik pada kelompok intervensi usia responden yang paling banyak adalah remaja putri dengan usia 16 tahun yaitu sebanyak 11 orang $(55,0 \%)$ sedangkan pada kelompok kontrol yang paling banyak adalah responden dengan usia 16 tahun juga 
yaitu sebanyak 12 orang $(60,0 \%)$, karakteristik usia menarche pada kelompok intervensi yang paling banyak yaitu usia 12 tahun sebanyak 8 orang $(40,0 \%)$ sedangkan pada kelompok kontrol sama usia 12 tahun sebanyak 8 orang $(40,0 \%)$, karakteristik siklus haid pada kelompok intervensi yang paling banyak siklus menstruasi 30 hari sebanyak 17 orang $(85,0 \%)$ dan pada kelompok kontrol yaitu, 30 hari sebanyak 18 orang $(90,0 \%)$ karakteristik lama haid pada kelompok intervensi yaitu 6 hari sebanyak 9 responden $(45,0 \%)$, pada kelompok kontrol yaitu 6 hari sebanyak 10 orang $(50,0 \%)$.

\section{Analisis Univariat}

Tabel 2. Distribusi Frekuensi Nyeri Saat Menstruasi

\begin{tabular}{lcccccc}
\hline \multicolumn{1}{c}{ Variabel } & N & Mean & $\begin{array}{c}\text { Media } \\
\mathbf{n}\end{array}$ & SD & Min & Max \\
\hline $\begin{array}{l}\text { Hasil Pengukuran nyeri Pada } \\
\text { kelompok diberi air kelapa } \\
\text { muda }\end{array}$ & 20 & 4,10 & 4 & 1,16 & 2 & 6 \\
\hline $\begin{array}{l}\text { Hasil Pengukuran nyeri Haid } \\
\begin{array}{l}\text { Pada kelompok yang tidak } \\
\text { diberi air kelapa }\end{array}\end{array}$ & 20 & 6,15 & 6 & 1,08 & 4 & 8 \\
\hline
\end{tabular}

Dari tabel di atas dapat diketahui bahwa pada kelompok yang diberi air kelapa muda sebanyak 20 responden, diperoleh hasil nilai mean atau nilai rata-rata nyeri menstruasi pada kelompok intervensi adalah sebesar 4,10 dengan nilai median 4, standar deviasi sebesar 1,16 , hasil skala nyeri terendah atau hasil skala nyeri minimal yaitu sebesar 2 dan hasil skala nyeri tertinggi atau hasil skala nyeri maximal sebesar 6. Sedangkan dapat diketahui dari 20 responden penelitian yang tidak diberi air kelapa muda, diperoleh hasil nilai mean atau nilai rata-rata nyeri menstruasi pada kelompok kontrol sebesar 6,15, dengan nilai median 6, standar deviasi sebesar 1,08, hasil skala nyeri terendah atau hasil skala nyeri minimal yaitu sebesar 4 dan hasil skala nyeri tertinggi atau hasil skala nyeri maximal sebesar 8 .

\section{Analisis Bivariat}

Tabel 3. Air Kelapa Muda Terhadap Rasa Nyeri Saat Menstruasi

\begin{tabular}{lccccc}
\hline \multicolumn{1}{c}{ Hasil Pengukuran nyeri } & $\mathrm{N}$ & Mean & SD & SE & $P$ value \\
\hline Kelompok Intervensi & 20 & 4,10 & 1,165 & 0,261 & 0.000 \\
\cline { 1 - 5 } Kelompok Kontrol & 20 & 6,15 & 1,089 & 0,244 & \\
\hline
\end{tabular}

Dari tabel diatas dapat dikethui hasil uji t didapat $p$ value $0,000<0.05$ artinya $\mathrm{H}_{0}$ ditolak dan $\mathrm{Ha}$ diterima, yang berarti ada pengaruh pemberian

\section{PEMBAHASAN}

\section{Rata-rata nyeri saat Menstruasi}

Berdasarkan hasil penelitian dari kedua kelompok. didapatkan rata-rata nyeri saat menstruasi pada siswi Di SMK Negeri 1 Bandar Lampung Tahun air kelapa muda terhadap rasa nyeri saat menstruasi Pada Siswi Di SMK Negeri 1 Bandar Lampung Tahun 2020.

2020 dengan kelompok yang diberi air kelapa muda, sebanyak 20 responden, diperoleh hasil nilai mean atau nilai rata-rata nyeri menstruasi pada kelompok intervensi adalah sebesar 4,10, dengan nilai median 4, standar 
deviasi sebesar 1,16 , hasil skala nyeri terendah atau hasil skala nyeri minimal yaitu sebesar 2 dan hasil skala nyeri tertinggi atau hasil skala nyeri maximal sebesar 7. Sedangkan berdasarkan hasil penelitian didapatkan hasil dari 20 responden penelitian yang tidak diberi air kelapa muda, diperoleh hasil nilai mean atau nilai rata-rata nyeri menstruasi pada kelompok kontrol sebesar 6,15, dengan nilai median 6, standar deviasi sebesar 1,08, hasil skala nyeri terendah atau hasil skala nyeri minimal yaitu sebesar 4 dan hasil skala nyeri tertinggi atau hasil skala nyeri maksimal sebesar 8 .

Nyeri haid merupakan keluhan yang sering dirasakan masyarakat sehingga menjadi penyebab yang paling banyak hilangnya waktu kerja atau absen masuk sekolah (Manuaba, 2010).Hampir semua perempuan mengalami rasa tidak nyaman selama haid, seperti rasa tidak enak diperut bagian bawah dan biasanya juga disertai mual, pusing, bahkan pingsan (Anurogo dan Wulandari, 2011).

Berdasarkan hasil penelitian yang telah didapatkan hampir sebagian remaja putri yang menjadi responden penelitian mengeluh merasakan ketidaknyamanan pada perut bagian bawah saat datang haid, ketidaknyamanan itu bervariasi mulai dari kram perut ringan, sampai dengan rasa sangat sakit/nyeri hingga menjalar sampai pinggang hal ini sangat mengganggu aktivitas khususnya proses belajar remaja-remaja putri tersebut ataupun aktivitas sehari-hari. Nyeri haid yang responden alamitermaksud dalam nyeri haid primer hal ini telah teridentifikasi sejak awal pengumpulan data dan dipastikan kembali saat akhir pengisian kuisioner, dengan demikian nyeri haid yang dialami responden tidak ada hubungannya dengan penyakit gynecologi bawaan dari masing-masing responden.

Nyeri haid yang dirasakan
masing-masing responden dalam
penelitian ini telah di ukur
menggunakan metode Numerical
Rating Scale (NRS) mulai dari nilai 0

sampai dengan 10 yang merupakan salah satu alat ukur untuk menilai tingkat nyeri yang dialami remaja tersebut sesuai subjektivitas yang dirasakan. Didapatkan nilai yang bervariasi atau berbeda beda hal ini disebabkan oleh beberapa hal yang mempengaruhi seorang remaja menilai rasa sakitnya di antaranya, faktor usia, usia menarche, siklus menstruasi dan lama menstruasi yang juga mempengaruhi tingkat nyeri haid responden sehingga tingkat nyeri yang dialami berbeda beda satu sama lain,

Tingkat nyeri tertinggi kelompok intervensi yaitu 6 dialami oleh 2 orang responden dengan usia 17 tahun, sedangkan untuk tingkat nyeri tertinggi pada kelompok kontrol adalah 8 dialami oleh 2 orang responden dengan usia 17 tahun. Kejadian dismenore primer sangat dipengaruhi oleh usia wanita. Rasa sakit yang dirasakan beberapa hari sebelum menstruasi dan saat menstruasi biasanya karena meningkatnya sekresi hormon prostaglandin. Semakin tua umur seseorang, semakin sering ia mengalami menstruasi dan semakin lebar leher rahim maka sekresi hormon prostaglandin akan semakin berkurang. Selain itu, dismenore primer nantinya akan hilang dengan semakin menurunnya fungsi saraf rahim akibat penuaan.

Usia menarche, berdasarkan penelitian yang telah dilakukan, usia termuda adalah usia 10 tahun, sebanyak 10 responden, 5 responden dari kelompok intervensi dan 5 kelompok kontrol (25\%). Pada kelompok intervensi tingkat nyeri tertinggi yaitu, 6 dialami oleh responden dengan usia menarche 10 tahun. Sedangkan untuk kelompok kontrol tingkat nyeri tertinggi yaitu 8 , juga dialami oleh responden dengan usia menarche 10 tahun. Tingginya tingkat nyeri haid juga dipengaruhi oleh usiamenarche.

Data siklus haid yang peneliti dapatkan dari 40 responden yang mengalami siklus haid $>35$ hari sebanyak 3 orang, 1 orang dari kelompok kontrol dengan tingkat nyeri 
8 yaitu nilai tertinggi dan 2 dari kelompok intervensi dengan tingkat nyeri 6 yang juga tingkat nilai tertinggi, sedangkan untuk 37 responden lainya memiliki riwayat siklus haid dalam batas normal yaitu 21-35 hari. Didapatkan siklus haid diluar siklus normal memiliki tingkat nyeri yang lebih tinggi.

Gangguan siklus haid, menyebabkan produksi prostaglandin saat menstruasi meningkat, haid yang panjang menyebabkan semakin banyaknya prostaglandin di uterus sedang peluruhan, selain itu kerja otot rahim meningkat karena durasi menstruasi yang panjang sehingga menyebabkan nyeri saat haid. Dalam jurnal ini dijelaskan juga bahwa remaja tahap akhir mengalami gangguan yang terkait dengan haid sebesar $75 \%$, yaitu menstruasi yang tertunda, tidak teratur, nyeri dan perdarahan yang banyak pada waktu haid merupakan keluhan yang menyebabkan remaja wanita menemui dokter.

Pada data lama nya haid didapatkan 7 responden dengan lama haid selama 7 hari, 4 responden pada kelompok intervensi $(20 \%)$ dan 3 responden pada kelompok kontrol $(15 \%)$, pada kelompok intervensi didapatkan responden dengan lama haid 7 hari mengalami nyeri haid dengan tingkat tertinggi yaitu 6 sebanyak 2 responden dan 2 responden lagi menderita nyeri dengan tingkat yaitu 5, untuk kelompok kontrol 2 responden yang lama haidnya sebanyak 7 hari menderita tingkat nyeri haid tertinggi 8 , dan 1 responden dengan tingkat nyeri haid 7. Dalam penelitian ini menunjukkan responden dengan lama hari lebih atau sama dengan 7 hari mengalami tingkat nyeri haid lebih tinggi. Produksi prostaglandin berlebihan menimbulkan rasa nyeri, sedangkan kontraksi uterus yang terus menerus menyebabkan suplai darah ke uterus terhenti dan nyeri haid. Usia responden, usia menarche, siklus haid dan lama nya haid merupakan beberapa faktor yang mempengaruhi variasi tingkat nyeri haid dalam penelitian ini, selain itu terdapat faktor lain yang perlu menjadi pertimbangan seperti, Kejiwaan/psikologis, ketahanan rasa sakit serta Obstruksi Kanalis Servikalis (Prawirohardjo, 2011) merupakan salah satu hal yang mempengaruhi tingkat nyeri haid yang mereka rasakan.

\section{Pengaruh Pemberian Air Kelapa Muda}

Berdasarkan hasil penelitian didapatkan hasil uji t didapat $p$ value $0,000<0.05$ artinya $\mathrm{H}_{0}$ ditolak dan $\mathrm{Ha}$ diterima, yang berarti ada pengaruh pemberian air kelapa muda terhadap nyeri saat Menstruasi (Dysmenorrhea) Pada Siswi Di SMK Negeri 1 Bandar Lampung Tahun 2020.

Pengobatan nyeri haid dapat dilakukan dengan pengobatan herbal, Bangsa Indonesia telah lama mengenal dan menggunakan tanaman berkhasiat obat salah satunya dalam upaya menanggulangi masalah kesehatan. Tidak hanya di tanah air obat herbal juga telah diterima secara luas hampir seluruh negara di dunia. WHO telah merekomendasikan penggunaan obat tradisional dalam pemeliharaan kesehatan masyarakat, pencegahan dan pengobatan penyakit. Pengobatan herbal yang dapat mengurangi nyeri haid adalah kayu manis, kedelai, cengkeh, kunyit, jahe, oso dresie, dan herbal cina, serta minyak ikan (Fikri \& Ismi, 2015).

Berdasarkan penelitian Kristina, dkk (2012) tentang "The Effect of Coconut Water on In Vitro Shoots Multiplication, Rhizome Yield, and Xanthorrhizol Content of Java Turmeric in Field" Air kelapa dapat merelaksasikan otot yang disebabkan oleh aktivitas prostaglandin, karna pada saat menstruasi, senyawa molekul yang disebut prostaglandin dilepaskan.

Pada saat menstruasi kadar Prostaglandin menurun sehingga menyebabkan terjadinya peningkatan sintesis prostaglandin. Menurut Berek dan Novak's, penurunan progesterone pada fase luteal membuat membran 
lisosomal menjadi tidak stabil dan memicu aksi enzim lisosomal, pelepasan enzim ini menyebabkan pelepasan enzim phospholipase yang berperan pada konversi fosfolipid menjadi asam arakidonat dan mengaktivasi jalur siklooksigenase (COX). Selanjutnya asam arakidonat menjadi PGF2a dan prostaglandin E2 (PGE2) melalui siklus endoperoxidase dengan perantara prostaglandin G2 (PGG2). Peningkatan prostaglandin ini mengakibatkan vasokontriksi pembuluh darah arteri spiralis. Vasokonstriksi arteri spiralis memberikan dampak iskemia endometrium bagian kompakta dan spongiosa sehingga, sehingga terjadi nekrosis (Manuaba,2010),

Hasil penelitian ini juga sejalan dengan penelitian yang telah dilakukan oleh Amiritha (2017) pada bulan juni 2017, yang menyatakan ada pengaruh antara nyeri haid remaja di Rusunawa Putri Universitas Muhammadiyah sebelum dan sesudah diberikan air kelapa muda dengan $p$ value $=0,000$ $(p<0,05)$. Penelitian tersebut menggunakan metode yang berbeda dengan peneliti lakukan namun mendapatkan hasil yang sama yaitu, pemberian air kelapa mempengaruhi nyeri haid. Air kelapa muda merupakan salah satu tindakan mandiri keperawatan. Responden yang telah ditreatment dalam penelitian ini didapatkan adanya penurunan nyeri haid, sesudah diberikan air kelapa muda. Hal ini karena saat menstruasi tubuh mengeluarkan cairan dan darah.

Penelitian ini juga sejalan dengan penelitian yang dilakukan dalam jurnal yang berjudul Cocos nucifera (L.) (Arecaceae) A phytochemical and pharmacological reviewoleh Lima, dkk (2015) menyatakan selain dapat menjadi infus (pengganti cairan tubuh) air kelapa muda juga dapat membantu mengurangi rasa nyeri saat menstruasi (Dysmenorrhea).Air kelapa mengandung efek biologis, seperti antihelminthic, antiinflamasi, aktivitas antinosiseptif, antioksidan, antijamur, antimikroba, dan antitumor yang dapat menangani keluhan (Dysmenorrhea) dan gangguan haid lainnya yang telah digunakan di beberapa negara.

MenurutH uzaimah (2015), bahwa air kelapa muda mengandung elektrolit, mineral, asam folat dan vitamin. Darah yang keluar dapat digantikan oleh asam folat. Asam folat membantu dalam proses pembentukan sel darah merah. Keluhan nyeri haid disebabkan karena adanya hiperkontraksi uterus dan ketidakseimbangan hormon progesteron dan prostaglandin. Vitamin dan mineral yang terkandung dalam air kelapa merangsang produksi progesteron dan prostaglandin dalam jumlah yang stabil. Kadar hormon yang cukup akan merangsang dan mempercepat proses peluruhan endometrium dan nyeri yang timbul akan segera berkurang. Rasa nyeri akan berkurang setelah keluar darah yang cukup banyak atau lancar.

Menurut pendapat peneliti dari responden yang telah diberikan air kelapa muda lebih cenderung mengalami tingkat nyeri haid yang lebih rendah dibandingkan dengan kelompok responden yang tidak diberikan air kelapa muda, hal ini telah terbukti dari hasil penelitian yang dilakukan, terdapat perbedaan yang signifikan dikarenakan air kelapa muda mengandung beberapa substansi yang dibutuhkan saat wanita mengalami haid.

Dari hasil pengumpulan data nyeri haid yang telah dilakukan menggunakan metode Numerical Rating Scale (NRS), mulai dari nilai 0 sampai dengan 10 yang merupakan salah satu alat ukur untuk menilai tingkat nyeri yang dialami remaja tersebut sesuai subjektivitas yang dirasakan. Sehingga terkumpul data yang menggambarkan nyeri yang dialami remaja putri di SMK Negeri 1 Bandar Lampung, namun tidak ditemukan nyeri dengan tingkat nyeri 0 pada kelompok intervensi pada proses pengumpulan data nilai tertinggi pada kelompok intervensi adalah 6 dan sebaliknya tidak juga ditemukan nilai 10 yaitu tingkat nyeri sangat berat pada kelompok kontrol tingkat nyeri 
tertinggi pada proses pengumpulan data adalah 8, hal ini dikarenakan pemberian air kelapa muda pada penelitian ini tidak serta merta dapat menghilangkan rasa nyeri yang sebelumnya remaja putri rasakan setiap bulanya menjadi menghilang, ataupun remaja putri yang tidak diberi air kelapa atau dalam penelitian ini diberi air mineral merasakan nyeri yang amat hebat.

Ada beberapa hal yang mempengaruhi Nyeri haid (Dysmenorrhea) yang dirasakan pada remaja putri hal yaitu, usia, Usia menarche, siklus menstruasi dan lama menstruasi oleh sebab itu respon nyeri yang dirasakan remaja putri tersebut berbeda-beda pula. Berdasarkan hasil penelitian dari karakteristik pada kelompok intervensi usia responden yang paling banyak adalah remaja putri dengan usia 16 tahun yaitu sebanyak 11 orang $(55,0 \%)$ sedangkan pada kelompok kontrol yang paling banyak adalah responden dengan usia 16 tahun juga yaitu sebanyak 12 orang $(60,0 \%)$, dan untuk tingkat nilai tertinggi pada kelompok intervensi adalah 6 dengan responden usia 17 tahun, dan pada kelompok kontrol nilai tertinggi adalah 8 dialami oleh responden dengan usia 17 tahun.

Karakteristik usia menarche pada kelompok intervensi yang paling banyak yaitu usia 12 tahun sebanyak 8 orang $(40,0 \%)$ sedangkan pada kelompok kontrol sama usia 12 tahun sebanyak 8 orang $(40,0 \%)$, Untuk nilai tertinggi pengukuran skala nyeri pada kelompok intervensi adalah 6 dialami oleh responden dengan usia menarche 10 tahun sedangkan tingkat nyeri tertinggi pada kelompok kontrol adalah 8 yang dialami oleh responden dengan usia sama yaitu, 10 tahun.

Karakteristik siklus haid pada kelompok intervensi yang paling banyak siklus menstruasi 30 hari sebanyak 17 orang $(85,0 \%)$ dan pada kelompok kontrol yaitu, 30 hari sebanyak 18 orang $(90,0 \%)$, untuk skala tingkat nyeri tertinggi pada kelompok intervensi yaitu, 6 dialami oleh responden dengan siklus menstruasi 36 hari dan pada kelompok kontrol responden dengan skala nyeri tertinggi yaitu, 8 memiliki siklus haid sama yaitu 36 hari. Karakteristik lama haid pada kelompok intervensi yaitu 6 hari sebanyak 9 orang $(45,0 \%)$, pada kelompok kontrol yaitu 6 hari sebanyak 10 orang $(50,0 \%)$. Untuk skala tingkat nyeri tertinggi pada kelompok intervensi yaitu, 6 mengalami lama menstruasi 7 hari dan responden dengan tingkat nyeri tertinggi pada kelompok kontrol yaitu, 8 mengalami lama menstruasi sama yaitu 7 hari.

\section{KESIMPULAN}

Ada Pengaruh Pemberian air kelapa muda Terhadap Rasa Nyeri Saat Menstruasi (Dysmenorrhea)Pada Siswi di SMK Negeri 1 Bandar Lampung Tahun 2020, hasil uji t didapat $p$ value $0,000<0,05$.

\section{SARAN}

$\begin{array}{lr}\text { Diharapkan untuk } & \text { dapat } \\ \text { menambah informasi dan } & \text { edukasi } \\ \text { kepada remaja putri untuk }\end{array}$ menyediakan air kelapa muda dirumah untuk dikonsumsi baik pada saat mengalami nyeri haid maupun tidak mengalami nyeri haid, karena selain manfaat yang melimpah air kelapa muda telah terbukti dapat menurunkan nyeri haid.

\section{DAFTAR PUSTAKA}

Ahuja, S. C., Ahuja, U., \& Ahuja, S. (2014). Coconut-History, Uses, and Folklore. Asian AgriHistory, 18(3).

Almatsier, S. (2010). Prinsip dasar ilmu gizi, PT. Gramedia Pustaka Utama, Jakarta.

Amiritha.(2017). Pengaruh Pemberian Air Kelapa Muda TerhadapPenuru nan Nyeri Haid

Remaja Di Rusunawa Putri Univer sitas Muhammadiyah Semarang.

Anurogo, D., \& Wulandari, A. (2011).Cara jitu mengatasi nyeri haid. Yogyakarta: Andi.

Data Register UKS SMK Negeri I Bandar Lampung Tahun 20182019 
Dewi, H. E. (2012). Memahami perkembangan fisik remaja. Yogyakarta: Gosyen Publishing.

Ekpenyong, E. E., \& Okafor, I. M. A. Cocos Nucifera Water: Therapeutic Benefits and Sickle Cell Anemia Review.

Fikri, Z., \& Ismi, N. (2015).Rebusan Daun Sirih Dan Kunyit Terhadap Keputihan Patologis Pada Remaja Putri (Piper Betle linn Leaf and Curcuma Longa linn Stew toward Fluor Albus). Journals of Ners Community, 6(1), 34-44.

Hastono, Sutanto Priyo. (2018). Statistik Kesehatan.Depok :Rajawali Pers.

Huzaimah, H. (2015). Studi Analisa Pemanfaatan Air Kelapa Sebagai Intervensi Non Farmakologi Dalam Mencegah Nyeri Haid (Disminorea) Pada Santriwati Di Asrama Al- Husna Pondok Pesantren Darul Ulum Jombang (Doctoral dissertation, Universitas Pesantren Tinggi Darul Ulum).

Kristina, N., \& Syahid, S. (2012). The Effect of Coconut Water on In Vitro Shoots Multiplication, Rhizome Yield, and Xanthorrhizol Content of Java Turmeric in Field. Jurnal Litrri, 18-125

Kusmiran,Eny. (2013). Kesehatan Reproduksi Wanita dan Remaja, Salemba Medika : Jakarta.

Lima, E. B. C., Sousa, C. N. S., Meneses, L. N., Ximenes, N. C., Júnior, S., Vasconcelos, G. S., ...\& Vasconcelos, S. M. M. (2015). Cocos nucifera
(L.)(Arecaceae): A phytochemical and pharmacological review. Brazilian Journal of Medical and Biological Research, 48(11), 953-964

Lingga,Lanny(2012)Terapi Kelapa. Jakarta : PT Elex Media Komputindo Kelompok Gramedia.

Manuaba, I. K. (2010). Penyakit Kandungan dan Pendidikan Keluarga Berencana Untuk Pendidikan Bidan. EGC, Jakarta.

Manuaba.I.B.G.(2010) Memahami Kesehatan Reproduksi Wanita Edisi 2, EGC: Jakarta.

Prawirohardjo, S., Wiknjosastro, H., \& Sumapraja, S. (2011). Ilmu Kandungan edisi ketiga. Jakarta: Yayasan Bina Pustaka Sarwono, 274-278. Putri, T. Keampuhan Air dan Minyak Kelapa bagi Kesehatan.LAKSANA.

Rahmawati, M. S. (2012). Pengaruh Pemberian Air Kelapa Muda Terhadap Penurunan Kelelahan Kerja Pada Pengrajin Di Home Industry Mie Krupuk Desa Harjosari Kidul Kabupaten Tegal Tahun 2011 (Doctoral dissertation, Universitas Negeri Semarang).

Sugiyono. (2016). Metode Penelitian Kuantitatif Kualitatif dan R\&D. Bandung: Alfabeta.

Sulistyorini, S., Monica, S., \& Ningsih, S. S. (2017). Faktor-Faktor Yang Mempengaruhi Kejadian

Disminorhea Primer Pada Siswi Sma Pgri 2 Palembang. Masker Medika, 5(1), 223-231. 